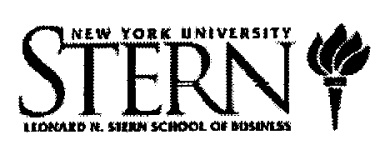

STERN

Universal Banking: A Shareholder Value Perspective

Walter, Ingo

FIN-96-40 



\title{
Universal Banking: A Shareholder Value Perspective
}

\author{
by \\ Ingo Walter \\ New York University
}

In their historical development, organizational structure, and strategic direction, universal banks constitute multi-product firms within the financial services sector. Certainly within their home environments, universal banks effectively target most or all client-segments, and make an effort to provide each with a full range of the appropriate financial services. Outside the home market, they usually adopt a narrower competitive profile, in the majority of cases focusing on wholesale banking and securities activities as well as international private banking - occasionally building a retail presence in foreign environments as well.

This stylized profile of universal banks presents shareholders with an amalgam of more or less distinct businesses that are linked-together in a complex network which draws on a set of centralized financial, information, human and organizational resources-a profile that tends to be extraordinarily difficult to manage in a way that achieves an optimum use of invested capital. The key issue for the investor is whether shares in a universal bank represent an attractive asset-allocation alternative from a perspective of both risk-adjusted total-return and portfolio-efficiency. The answers to this question, in turn, have an important bearing on the universal bank's cost of capital and therefore its performance against rivals with a narrower business focus in increasingly competitive markets. 
This paper considers these issues within a straightforward conceptual framework. I begin by adding to presumptive adjusted book value of a universal bank's equity a number of building-blocks that ultimately determine the market value of its equity. I then ask whether that market value of equity is in fact the maximum value attainable from the perspective of the shareholder. Finally, I outline some of the strategic and tactical alternatives, inside and outside the bank, that are open to management in order to achieve a hypothetical maximum value of shareholder equity. Whatever empirical evidence is available in the literature is brought to bear in the course of the discussion.

\section{Structure of the Universal Bank}

Universal banking organizations may take a number of more or less distinct forms. ${ }^{1}$ These are stylized in Exhibit 1.

- A fully-integrated universal bank (Type-A) provides a broad range of financial services (banking, securities and insurance) under a single corporate structure supported by a single capital base. There are, at present, no good examples of this particular model.

- A partially integrated universal bank (Type-B) conducts both commercial and investment banking within the same entity, but undertakes insurance underwriting and distribution, as well as mortgage banking, asset management, lease-financing, factoring, management consulting, and other specialized activities through separately-capitalized subsidiaries, either because such activities are separately regulated, or because they involve significant potential for exploitation of conflicts of interest, or a combination of such factors. Deutsche Bank AG would be a good example of this type of universal banking structure.

\footnotetext{
${ }^{1}$ For a detailed discussion, see Saunders and Walter [1994].
} 
- In a Type-C universal bank the commercial bank, whose core business is taking deposits and making commercial loans, is the parent of subsidiaries engaged in a variety of other financial services ranging from investment banking to insurance. An example would be Barclays Plc.

- A final universal banking structure (Type-D) involves creation of a holding company which controls affiliates engaged in commercial banking, investment banking, insurance, and possibly other types of financial and nonfinancial businesses. Examples include J.P. Morgan and CS Holding.

The specific structures that universal banks adopt are driven by regulatory considerations, by the production-function characteristic of financial services, and by demand-side issues relating to market structure and client preferences. American regulation, for example, mandates a Type-D form of organization, with the GlassSteagall provisions of the Banking Act of 1933 requiring separation of banking (taking deposits and extending commercial loans) and most types of securities activities (underwriting and dealing in corporate debt and equities and their derivatives, as well as state and local revenue bonds). Each type of business must be carried out through separately-capitalized subsidiaries, and there are strict "firewalls" between them. U.S. bank holding companies are also enjoined from most types of insurance underwriting and distribution. British universal banking follows the Type-C model, with securities and insurance activities carried out via subsidiaries of the bank itself. Most continental European countries seem to follow the Type-B model, with full integration of banking and securities activities within the bank itself (despite functional regulation), and insurance, mortgage banking and other specialized financial and nonfinancial activities carried out through subsidiaries. As noted, the Type-A universal banking model, with all activities carried out within a single corporate entity, seems not to exist even in 
environments characterized by a monopoly regulator such as, for example, the Monetary Authority of Singapore.

From a production-function perspective, the structural form of universal banking appears to depend on the ease with which operating efficiencies and scale and scope economies can be exploited-determined in large part by product and process technologies - as well as the comparative organizational effectiveness in optimally satisfying client requirements and bringing to bear market power. ${ }^{2}$

\section{From Book Value of Equity to Market Value of Equity}

Realization of shareholder value can begin by tracing the sources of valueincrements in excess of book value of equity (BVE). For universal banks, the BVE is the sum of: (1) The par value of shares when originally issued; (2) The surplus paid-in by investors when the shares were issued; (3) Retained earnings on the books of the bank; and (4) Reserves set aside for loan losses [Saunders, 1996]. Depending on the prevailing regulatory and accounting system, BVE must be increased by unrealized capital gains associated with assets such as equity holdings carried on the books of the bank at historical cost and their prevailing replacement values (hidden reserves), as well as the replacement values of other assets and liabilities that differ materially from historical values due to credit and market risk considerations-i.e., their mark-tomarket values.

\footnotetext{
${ }^{2}$ In this context, Switzerland presents and interesting case study, with the three major universal banks operating under a single set of domestic regulatory parameters having adopted rather different structural forms in the past but with more recent signs of substantial convergence.
} 
We thus have the presumptive adjusted book value of equity (ABVE), which in fact is not normally revealed in bank financial statements due to a general absence of market- value accounting across broad categories of universal banking activities - with the exception of trading-account securities, derivatives and open foreign exchange positions, for example.

As in nonfinancial firms like McDonalds, Coca-Cola or any other publicly traded firm, shareholder interests in a universal bank are tied to the market value of its equity (MVE) - the number of shares outstanding times the prevailing market price. MVE normally should be significantly in excess of $A B V E$, reflecting as it does current and expected future net earnings, adjusted for risk. The MVE/ABVE so-called " $Q$ " ratio can, however, be either higher or lower than 1 , and is clearly susceptible to enhancement through managerial or shareholder action. If it is significantly below 1 , for example, it may be that breaking-up the bank can serve the interests of shareholders-if ABVE or more can be realized as a result-in the same way as restructurings have raised shareholder value under appropriate circumstances in industrial companies.

Assuming a universal bank's MVE exceeds ABVE, what factors can explain the difference? Exhibit 2, begins with ABVE and sequentially identifies incremental-value sources to arrive at MVE, which are explained in the following sections.

\section{Economies of Scale}

Whether economies of scale exist in financial services has been at the heart of strategic and regulatory discussions about optimum firm size in the financial services 
sector-can increased size increase shareholder value? In an information- and distribution-intensive industry with high fixed costs, such as financial services, there should be ample potential for scale economies-as well as potential for diseconomies of scale attributable to administrative overhead, agency problems and other cost factors once very large firm-size is reached. If economies of scale prevail, increased size will help create shareholder value. If diseconomies prevail, shareholder value will be destroyed. Large banks themselves vary greatly in asset size, ranging among the world's top-100 at year-end 1995, for example, from BancOne's \$ 91 billion (ranked 95th) through Chase Manhattan's \$121 billion (ranked 70th), J.P. Morgan's \$185 billion (ranked 47th) and Union Bank of Switzerland's \$235 billion (ranked 16th), to Deutsche Bank's $\$ 502$ billion (ranked 4th) and Mitsubishi-Tokyo's $\$ 723$ billion, ranked first. Bankers regularly argue that "bigger is better" from a shareholder value perspective, and usually point to economies of scale as a major reason why.

\section{Economies of Scope}

There should also be ample potential for economies and diseconomies of scope in the financial services sector, which may arise either through supply- or demand-side linkages. $^{3}$

On the supply side, scope economies relate to cost-savings through sharing of overheads and improving technology through joint production of generically similar

\footnotetext{
${ }^{3}$ This market-profile can be depicted as covering the full state-space of the domestic arena of the C-A-P taxonomy presented in Walter [1988] and using that as a platform to target a narrower range of (usually wholesale) financial services and clients in offshore and national markets abroad.
} 
groups of services. Supply-side diseconomies of scope may arise from such factors as inertia and lack of responsiveness and creativity that may come with increased firm size and bureaucratization, "turf" and profit-attribution conflicts that increase costs or erode product quality in meeting client needs, or serious cultural differences across the organization that inhibit seamless delivery of a broad range of financial services.

On the demand side, economies of scope (cross-selling) arise when the all-in cost to the buyer of multiple financial services from a single supplier-including the price of the service, plus information, search, monitoring, contracting and other transaction costs - is less than the cost of purchasing them from separate suppliers. Demand-related diseconomies of scope could arise, for example, through agency costs that may develop when the multi-product financial firm acts against the interests of the client in the sale of one service in order to facilitate the sale of another, or as a result of internal information-transfers considered inimical to the client's interests. Management of universal banks often argues that broader product and client coverage, and the increased throughput volume this makes possible, represents shareholder-value enhancement.

Network economics associated with universal banking may be considered a special type of demand-side economy of scope. [Economides, 1995] Like telecommunications, banking relationships with end-users of financial services represent a network structure wherein additional client linkages add value to existing clients by increasing the feasibility or reducing the cost of accessing them - so-called "network externalities" which tend to increase with the absolute size of the network itself. Every 
client link to the bank potentially "complements" every other one and thus potentially adds value through either one-way or two-way exchanges though incremental information or access to liquidity. The size of network benefits depends on technical compatibility and coordination in time and location, which the universal bank is in a position to provide. And networks tend to be self-reinforcing in that they require a minimum critical mass and tend to grow in dominance as they increase in size, thus precluding perfect competition in network-driven financial services. This characteristic is evident in activities such as securities clearance and settlement, global custody, funds transfer and international cash management, forex and securities dealing, and the like. And networks lend to lock-in users insofar as switching-costs tend to be relatively high, creating the potential for significant market power.

\section{X-efficiency}

Besides economies of scale and scope, it seems likely that universal banks of roughly the same size and providing roughly the same range of services may have very different cost levels per unit of output. There is ample evidence of such performance differences, for example, in comparative cost-to-income ratios among banks both within and between national financial-services markets. The reasons involve efficiencydifferences in the use of labor and capital, effectiveness in the sourcing and application of available technology, and perhaps effectiveness in the acquisition of productive inputs, organizational design, compensation and incentive systems - and just plain better management. 
X-efficiency may be related to size if, for example, large organizations are differentially capable of the massive and "lumpy" capital outlays required to install and maintain the most efficient information-technology and transactions-processing infrastructures. Exhibit 3 shows information technology spend-levels that only large banks can afford. If such spend-levels result in higher X-efficiency, then large banks will gain in competition with smaller ones from a shareholder-value perspective. However, smaller organizations ought to be able to pool their resources or outsource in order to capture similar efficiencies. From a shareholder-value point of view, management is (or should be) under constant pressure though their boards of directors to do better, to maximize X-efficiency in their organizations, and to transmit this pressure throughout the enterprise.

\section{Empirical Evidence of Economies of Scale, Scope and X-efficiency}

What is the evidence regarding economies of scale, economies of scope and Xefficiency with regard to bank performance?

Individually or in combination, economies (diseconomies) of scale and scope in universal banks will either be captured as increased (decreased) profit margins or passed along to clients in the form of lower (higher) prices resulting in a gain (loss) of market share. They should be directly observable in cost functions of financial services suppliers and in aggregate performance measures.

Studies of scale and scope economies in financial services are unusually problematic. The nature of the empirical tests used, the form of the cost functions, 
the existence of unique optimum output levels, and the optimizing behavior of financial firms all present difficulties. Limited availability and conformity of data present serious empirical problems. And the conclusions of any study that has detected for failed to detect) economies of scale and/or scope in a sample selection of financial institutions does not necessarily have general applicability.

Many such studies have been undertaken in the banking, insurance and securities industries over the years (see Exhibit 4). Estimated cost functions form the basis most of these empirical tests, virtually all of which found the economies of scale are achieved with increases in size among small banks (below $\$ 100$ million in asset size). More-recent studies have shown the that scale economies may also exist in banks falling into the $\$ 100$ million to $\$ 5$ billion range. There is very little evidence so far of scale economies in the case of banks larger than $\$ 5$ billion. An examination of the world's 200 largest banks [Saunders and Walter, 1994] found evidence that very largest banks grew more slowly than the smaller among the large banks during the 1980 s, but that limited economies of scale did appear among the banks included in the study. Overall, the consensus seems to be that scale economies and diseconomies do not result in more than about $5 \%$ difference in unit costs. So, for most universal banks scale economies seem to have relatively little bearing on shareholder value in terms of Exhibit 2.

With respect to supply-side economies of scope, most empirical studies have failed to find such gains in the banking, insurance and securities industries, and most of them have also concluded that some diseconomies of scope are encountered when 
firms in the financial services sector add new product-ranges to their portfolios. Saunders and Walter [1994], for example, found negative supply-side economies of scope among the world's 200 largest banks - as the product range widens, unit-costs seem to go up.

As shown in Exhibit 4, scope economies in most other cost studies of the financial services industry are either trivial or negative. However, the period covered by many of these studies involved institutions that were rapidly shifting away from a pure focus on commercial banking, and may thus have incurred considerable costs in expanding the range of their activities. If this diversification effort involved significant sunk costs - which were expensed on the accounting statements during the period under study - that were undertaken to achieve future expansion of market-share or increases in fee-based areas of activity, then we might expect to see any strong statistical evidence of diseconomies of scope between lending and non-lending activities reversed in future periods. If the banks' investment in staffing, training, and infrastructure in fact bear returns in the future commensurate with these expenditures, then neutrality or positive economies of scope may well exist. Still, the available evidence remains inconclusive.

It is also reasonable to suggest that some demand-related scope economies may exist, but that these are likely to be very specific to the types of services provided and the types of clients involved. Strong cross-selling potential may exist for retail and private clients between banking, insurance and asset management products (one-stop shopping), for example. Yet such potential may be totally absent between trade- 
finance and mergers and acquisitions advisory services for major corporate clients. So demand-related scope economies are clearly linked to a universal bank's specific strategic positioning across clients, products and geographic areas of operation [Walter, 1988]. Indeed, a principal objective of strategic positioning in universal banking is to link market-segments together in a coherent pattern-what might be termed "strategic integrity" - that permits maximum exploitation of cross-selling opportunities, and the design of incentives and organizational structures to ensure that such exploitation actually occurs.

With respect to X-efficiency, a number of authors have found very large disparities in cost structures among banks of similar size, suggesting that the way banks are run is more important that their size or the selection of businesses that they pursue [Berger, Hancock and Humphrey, 1993; Berger, Hunter and Timme, 1993]. The consensus of studies conducted in the United States seems to be that average unit costs in the banking industry lie some $20 \%$ above "best practice" firms producing the same range and volume of services, with most of the difference attributable to operating economies rather than differences in the cost of funds [Akhavein, Berger and Humphrey, 1996]. Siems [1996] finds that the greater the overlap in branch-office networks, the higher the abnormal equity returns in U.S. bank mergers, while no such abnormal returns are associated with increasing concentration levels in the regions where the bank mergers occurred. This suggests that shareholder value in the megamergers of the mid-1990s was more associated with increases of X-efficiency than with reductions in competition. 
Specifically with respect to X-efficiency in universal banking Steinherr [1996] has assessed the profit performance and earnings variability of segmented and universal financial institutions worldwide during the late 1980s. Segmented and universal banks are found to have achieved roughly the same profit levels, but universal banks were found to have both lower cost levels and (interestingly) lower credit losses, which the author attributes to better monitoring of their clients based on private (non-public) information that universal banks may enjoy over their segmented counterparts. One explanation for this finding may be that Hausbank relationships, which represent an important aspect of universal banking in some countries, include the periodic conversion of bank debt to equity as part of credit workouts of nonfinancial clients in trouble, thus obviating the need to realize the extent of credit losses.

Taken together, these studies suggest very limited scope for cost economies of scale and scope among major universal banks. Scope economies, to the extent they exist, are likely to be found mainly on the demand side, and tend to apply very differently to different client segments. It is X-efficiency that seems to be the principal determinant of observed differences in cost levels among banks.

Perhaps contrary to conventional wisdom, therefore, there appears to be room in financial systems for viable financial services firms that range from large to small and from universal to specialist in a rich mosaic of institutions, as against a competitive landscape populated exclusively by 800 -pound gorillas. 


\section{Absolute Size and Market Power}

Still, conventional wisdom may win out in the end if large universal banks are able to extract economic rents from the market by application of market power-an issue that most empirical studies have not yet examined. Indeed, in many national markets for financial services suppliers have shown a tendency towards oligopoly but may be prevented by regulation or international competition from fully exploiting monopoly positions. Financial services market structures differ widely among countries, as measured for example by the Herfindahl-Hirshman index, ${ }^{4}$ with very high levels of concentration in countries such as the Netherlands and Denmark and low levels in relatively fragmented financial systems such as the United States. Lending margins and financial services fees, for example, tend to be positively associated with higher concentration levels. So do cost-to-income ratios. Shareholders naturally tend to gain from the former, and lose from the latter.

Certainly in global wholesale banking there is very little evidence so far that size as conventionally measured makes much difference in determining market share. Of the 1995 top-10 firms in terms of fixed-income and equity underwriting, loan syndications and M\&A mandates only one, CS - First Boston, is a universal bank-see Exhibits $5(a)$ and $5(b)$. This has been the case for over a decade. Still, there are plenty of universal banks in the top-20 and virtually all have a stated objective of top- 10

\footnotetext{
${ }^{4}$ The Herfindahl-Hirshman index is the sum of the squares market shares $\left(H=\sum s^{2}\right)$, where $0<H<10,000$ and market shares are measures, for example, by deposits, by assets, or by capital. $H$ rises as the number of competitors declines and as market-share concentration rises among the largest firms among a given number of competitors.
} 
status in the next five or ten years. This suggests a hypercompetitive global wholesale market, prevailing well into the future, as universal banks and more-specialized independent investment banks struggle for position in dealing with increasingly sophisticated wholesale issuer and investor clients, and with the emergence of a highly profitable "global bulge bracket" - limited to the privileged few-far less than a surething. So shareholders of universal banks looking for large risk-adjusted excess returns from their global wholesale banking operations would do well to fasten their seat belts. On the other hand, major universal banks may also be in a better position to lobby for favorable regulatory structures, so that it is not only competitive structure but also competitive conduct that may turn out to be favorable to their shareholders. Exhibit 6 shows the impact on market-to-book values of British banks after the U.K. clearing cartel was created in the 1920 s, followed by market-to-book erosion after the cartel was abolished in the 1970s. Differences in competitive structure are also illustrated in Exhibit 7, which compares the price-to-book ratios of U.S. money center banks to major regional banks, with the latter operating in substantially less competitive markets than the former.

\section{The Value of Income-stream Diversification}

Saunders and Walter [1994] carried out a series of simulated mergers between U.S. banks, securities firms and insurance companies in order to test the stability of earnings of the "merged" as opposed to separate institutions. The authors evaluated the "global" opportunity-set of potential mergers between existing money-center 
banks, regional banks, life insurance companies, property and casualty insurance companies and securities firms, and the risk-characteristics of each possible combination. The results were reported in terms of the average standard deviation of returns, along with the returns and risk calculated for the minimum-risk portfolio of activities. The findings suggest that there are potential risk-reduction gains from diversification in universal financial services organizations, and that these gains increase with the number of activities undertaken. The main risk-reduction gains appear to arise from combining commercial banking with insurance activities, rather than with securities activities. ${ }^{5}$ In the two-activity case, the best (lowest risk) merger partners for U.S. money-center banks were property and casualty insurers. In the three-activity case, the lowest-risk merger combination turned out to be between money center banks, regional banks and property and casualty insurers. In the full fiveactivity case (an average of 247,104 potential merger combinations among financial firms in the database), the standard deviation of returns was .01452 , well below the average risk level for money center banks $(.02024)$ on a stand-alone basis. ${ }^{6}$

Such studies, of course, may exaggerate the risk-reduction benefits of universal banking because they ignore many of the operational costs involved in setting up these activities. ${ }^{7}$ Moreover, to the extent that these ex-post risk measures reflect existing

\footnotetext{
${ }^{5}$ Much the same conclusions to these have been reached by Boyd, Graham and Hewitt (1990) using a similar methodological approach.

${ }^{6}$ Much the same conclusions to these have been reached by Boyd, Graham and Hewitt (1990) using a similar methodological approach.

7That is, only the financial firms in existence for the full 1984-88 period are considered.
} 
central-bank safety nets, they may underestimate the ex-ante risk in the future. At best, such results may be viewed as illustrative of the risk-reduction potential of universal banking. ${ }^{8}$ It seems unlikely that the diversification benefits in terms of riskreduction outweigh the negative earnings implications of less-than-optimum intra-firm capital allocation from the perspective of universal bank shareholders.

\section{Access to Bailouts}

It is certainly possible that the purported advantages of universal banking structures can result in a competitive landscape that is dominated by a small number of large institutions. In such a case, failure of one of the major institutions is likely to cause unacceptable systemic problems, and the institution will be bailed-out by taxpayers - as happened in the case of comparatively much smaller institutions in the United States, Switzerland, Norway, Sweden, Finland, and Japan during the 1980s and early 1990 s. If this turns out to be the case, then too-big-to-fail guarantees create a potentially important public subsidy for universal banking organizations and therefore implicitly benefit the institutions' shareholders.

On the other hand, "free lunches" usually don't last too long, and sooner or later such guarantees invariably come with strings attached. Possible reactions include intensified regulation of credit- and market-risk exposures, stronger supervision and surveillance intended to achieve early closure in advance of capital depletion, and

\footnotetext{
${ }^{8}$ However, it might be noted that White $(1986)$ has produced evidence to show that there were actual risk-diversification gains to banks' engaging in securities activities via affiliates (pre-1933 in the U.S.I, i.e., before the Glass-Steagall Act of 1933 required a separation of commercial banking from investment banking (securities activities).
} 
structural barriers to force activities into business units that can be effectively supervised in accordance with their functions even at the cost of a lower levels of Xefficiency and scope economies. The speed with which the central banks and regulatory authorities reacted to the 1996 Sumitomo copper trading scandal signaled the possibility of safety-net support of the global copper market, in view of major banks' massive exposures in highly complex structured credits. The fact is that toobig-to-fail guarantees are alive and well for all large banks-not only universal banks-as is public concern about what restrictions on bank activities ought to accompany them.

\section{Conflicts of Interest}

The potential for conflicts of interest is endemic in universal banking, and runs across the various types of activities in which the bank is engaged. The matrix presented in Exhibit 8 provides a simple framework for a taxonomy of conflicts of interest that may arise across the broad range of activities engaged in by universal banks. The major types of conflicts include the following: ${ }^{9}$

- Salesman's stake. It has been argued that when banks have the power to sell affiliates' products, managers will no longer dispense "dispassionate" advice to clients. Instead, they will have a salesman's stake in pushing "house" products, possibly to the disadvantage of the customer.

- Stuffing fiduciary accounts. A bank that is acting as an underwriter and is unable to place the securities in a public offering - and is thereby exposed to a potential underwriting loss-may seek to ameliorate this loss by "stuffing" unwanted securities into accounts managed by its investment department over

${ }^{9}$ For a detailed discussion, see Saunders \& Walter [1994], Chapter 6. 
which the bank has discretionary authority.

- Bankruptcy-risk transfer. A bank with a loan outstanding to a firm whose bankruptcy risk has increased, to the private knowledge of the banker, may have an incentive to induce the firm to issue bonds or equities-underwritten by its securities unit - to an unsuspecting public. The proceeds of such an issue could then be used to pay-down the bank loan. In this case the bank has transferred debt-related risk from itself to outside investors, while the it simultaneously earns a fee and/or spread on the underwriting. ${ }^{10}$

- Third-party loans. To ensure that an underwriting goes well, a bank may make below-market loans to third-party investors on condition that this finance is used to purchase securities underwritten by its securities unit.

- Tie-ins. A bank may use its lending power activities to coerce or tie-in a customer to the "securities products" sold by its securities unit. For example, it may threaten to credit-ration the customer unless it purchases certain investment banking services.

- Information transfer. In acting as a lender, a bank may become privy to certain material inside information about a customer or its rivals that can be used in setting prices or helping in the distribution of securities offerings underwritten by its securities unit. This type of information-flow could work in the other direction as well-i.e., from the securities unit to the bank.

Mechanisms to control conflict of interest-or more precisely, disincentives to exploit such conflicts-may be either market-based, regulation-based, or some combination of the two. Most universal banking systems seem to rely on market disincentives to prevent exploitation of opportunities for conflicts of interest. The United States has had a tendency since the 1930 s to rely on regulations, and in particular on "walls" between types of activities. In most countries, however, few impenetrable walls exist between banking and securities departments within the

\footnotetext{
${ }^{10} \mathrm{~A}$ recent example is the 1995 underwriting of a secondary equity issue of the Hafnia Insurance Group by Den Danske Bank, distributed heavily to retail investors, with proceeds allegedly used to pay-down bank loans even as Hafnia slid into bankruptcy. This case is now before the courts. See Smith and Walter [1997B].
} 
universal bank, and few external firewalls exist between a universal bank and its nonbank subsidiaries (e.g., insurance).$^{11}$ Internally, there appears to be a primary reliance on the loyalty and professional conduct of bank employees, both with respect to the institution's long-term survival and the best interests of its customers. Externally, reliance appears to be placed on market reputation and competition as disciplinary mechanisms. The concern of a bank for its reputational "franchise" and fear of competitors are viewed as enforcing a degree of control over the potential for conflict exploitation.

Shareholders clearly have a stake in the management and control of conflicts of interest in universal banks. They can benefit from conflict-exploitation in the short term, to the extent that business volumes and/or margins are increased as a result. On the one hand, preventing conflicts of interest is an expensive business. Compliance systems are costly to maintain, and various types of walls between business units can have high opportunity costs because of inefficient use of information within the organization. Externally, reputation losses associated with conflicts of interest can bear on shareholders very heavily indeed, as demonstrated by a variety of recent "accidents" in the financial services industry. It could well be argued that conflicts of interest may contribute to the MVE/ABVE ratios of universal banks falling below those of non-universal financial institutions. ${ }^{12}$

\footnotetext{
"For a comprehensive catalog of potential conflicts of interest, see Gnehm and Thalmann [1989].

${ }^{12} \mathrm{~A}$ detailed discussion is contained in Smith and Walter [1997A], Chapter 8.
} 


\section{Conglomerate Discount}

It is often alleged that the shares of multi-product firms and conglomerates tend (all else equal) to trade at prices lower than shares of more narrowly-focused firms. There are two reasons why this "conglomerate discount" is alleged to exist.

First, it is argued that, on balance, conglomerates use capital inefficiently. Recent empirical work by Berger and Ofek [1995] assesses the potential benefits of diversification (greater operating efficiency, less incentive to forego positive net present value projects, greater debt capacity, lower taxes) against the potential costs (higher management discretion to engage in value-reducing projects, crosssubsidization of marginal or loss-making projects that drain resources from healthy businesses, mis-alignments in incentives between central and divisional managers). The authors demonstrate an average value-loss in multi-product firms on the order of $13-15 \%$, as compared to the stand-alone values of the constituent businesses for a sample of U.S. corporations during the period 1986-91. This value-loss was smaller in cases where the multi-product firms were active in closely-allied activities within the same two-digit standard industrial code (SIC) classification.

The bulk of the value-erosion in conglomerates is attributed by the authors mainly to overinvestment in marginally profitable activities and cross-subsidization. In empirical work using event-study methodology, John and Ofek [1994] show that asset sales by corporations result in significantly improved shareholder value for the remaining assets, both as a result of greater focus in the enterprise and value-gains 
through high prices paid by asset buyers. Such findings from event-studies of broad ranges of industry may well apply to the diversified activities encompassed by universal banks as well. If retail banking and wholesale banking are evolving into highly-specialized performance-driven businesses, one may ask whether the kinds of conglomerate discounts found in industrial firms may not also apply to universal banking structures as centralized decision-making becomes increasingly irrelevant to the requirements of the specific businesses themselves.

A second possible source of a conglomerate discount is that investors in shares of conglomerates find it difficult to "take a view" and add pure sectoral exposures to their portfolios. Shareholders in companies like General Electric, for example, in effect own a closed-end mutual fund comprising aircraft engines, plastics, electricity generation and distribution equipment, financial services, diesel locomotives, large household appliances, and a variety of other activities. GE therefore presents investors who may have a bullish view of the aircraft engine business - which they would like reflected in their portfolio selection - with a particularly poor choice compared with Rolls Royce, for example, which is much more of a "pure play" in this sector. Nor is it easily possible to short the undesirable parts of GE in order to "purify" the selection of GE shares under such circumstances. So investors tend to avoid such stocks in their efforts to construct efficient asset-allocation profiles, especially highly performancedriven managers of institutional equity portfolios under pressure to outperform equity indexes.

The portfolio logic of the conglomerate discount should apply in the financial 
services sector as well, and a universal bank that is active in retail banking, wholesale commercial banking, middle-market banking, private banking, corporate finance, trading, investment banking, asset management and perhaps other businesses in effect represents a financial conglomerate that prevents investors from optimizing asset allocation across specific segments of the financial services industry.

Both the portfolio-selection effect and the capital-misallocation effect may weaken investor demand for universal bank shares, lower equity prices, and produce a higher cost of capital than if the conglomerate discount were absent-this in turn having a bearing on the competitive performance and profitability of the enterprise.

\section{Nonfinancial Shareholdings}

The conglomerate issue tends to be much more serious when a universal bank owns large-scale shareholdings in nonfinancial corporations, in which case the shareholder obtains a closed-end fund that has been assembled by bank managers for various reasons over time, and may bear no relationship to the investor's own portfolio optimization goals. The value of the universal bank itself then depends on the total market value of its shares, which must be held on an all-or-nothing basis, plus its own market value.

There are wide differences in the role banks play in nonfinancial corporate shareholdings and in the process of corporate governance [Walter, 1993]. These are stylized in Exhibit 9).

- In the equity-market system, industrial firms are "semi-detached" from banks. Financing of major corporations is done to a significant extent through the 
capital markets, with short-term financing needs satisfied through commercial paper programs, longer-term debt through straight or structured bond issues and medium-term note programs, and equity financing accomplished through public issues or private placements. Research coverage tends to be extensive. Commercial banking relationships with major companies can be very important - notably through backstop credit lines and short-term lending facilities-but they tend to be between buyer and seller, with close bank monitoring and control coming into play mainly for small and medium-size firms or in cases of credit problems and workouts. Corporate control in such "Anglo-American" systems tend to be exercised through the takeover market on the basis of widely-available public information, with a bank's function limited mainly to advising and financing bids or defensive restructurings. The government's role is normally arm's length in nature, with a focus on setting ground-rules that are considered to be in the public interest. Relations between government, banks and industry are sometimes antagonistic. Such systems depend heavily on efficient conflict-resolution mechanisms.

The second, bank-based approach centers on close bank-industry relationships, with corporate financing needs met mainly by retained earnings and bank financing. The role of banks carries well beyond credit-extension and monitoring to share ownership, share voting and board memberships in such "Germanic" systems. Capital allocation, management changes, and restructuring of enterprises is the job of non-executive supervisory boards on the basis of largely private information, and unwanted takeovers are rare. Mergers and acquisitions activity tends to be undertaken by relationship universal banks. Capital markets tend to be relatively poorly developed with respect to both corporate debt and equity, and there is usually not much of an organized venture capital market. The role of the state in the affairs of banks and corporations may well be arm's length in nature, although perhaps combined with some public-sector shareholdings.

Third, in the so-called "crossholding approach," interfirm boundaries are blurred through equity crosslinks and long-term supplier-customer relationships. Banks may play a central role in equity crossholding structures-as in Japan's "keiretsu" networks-and provide guidance and coordination as well as financing. There may be strong formal and informal links to government on the part of both the financial and industrial sectors of the economy. Restructuring tends to be done on the basis of private information by drawing on these business-banking-government ties, and a contestable market for corporate control tends to be virtually non-existent.

- The state-centered approach-perhaps best typified in the French traditioninvolves a strong role on the part of government through national ownership or 
control of major universal banks and corporations, as well as governmentcontrolled central savings institutions. Banks may hold significant stakes in industrial firms and form an important conduit for state influence of industry. Financing of enterprises tends to involve a mixture of bank credits and capital market issues, often taken up by state-influenced financial institutions. Additional channels of government influence may include the appointment of the heads of state-owned companies and banks, with strong personal and educational ties within the business and government élite.

These four stylized bank-industry-government linkages make themselves felt in the operation of universal banks in various ways. The value of any bank shareholdings in industrial firms is embedded in the value of the bank. The combined value of the bank itself and its industrial shareholdings, as reflected in its market capitalization, may be larger or smaller than the sum of their stand-alone values. For example, firms in which a bank has significant financial stakes, as well as a direct governance role, may be expected to conduct most or all significant commercial and investment banking activities with that institution, thus raising the value of the bank. On the other hand, if such "tied" sourcing of financial services raises the cost of capital of client corporations, this will in turn be reflected in the value of bank's own shareholdings, and the reverse if such ties lower client firms' cost of capital. Moreover, permanent bank shareholdings may stunt the development of a contestable market for corporate control, thereby impeding corporate restructuring and depressing share prices which in turn are reflected in the value of the bank to its shareholders. Banks may also be induced to lend to affiliated corporations under credit conditions that would be rejected by unaffiliated lenders, and possibly encounter other conflicts of interest that may ultimately make it more difficult to maximize shareholder value. 


\section{Franchise Value}

The foregoing considerations should, in combination, explain a significant part of any difference between the adjusted book value of equity and the market value of equity of a universal bank. But even after all such factors have been taken into account and priced-out, there may still be a material difference between the resulting "constructed" value of equity and the banks' market value (see Exhibit 2). The latter represents the market's assessment of the present value of the risk-adjusted future net earnings stream, capturing all known or suspected business opportunities, costs and risks facing the institution. The residual can be considered the "franchise" value of the bank. Much of it is associated with reputation and brand-value. Franchise value may be highly positive, as in the case of Coca-Cola for example, or it could be significantly negative, with the firm's stock trading well below its constructed value or even its adjusted book value - for example, if there are large prospective losses imbedded in the bank's internal or external portfolio of activities.

Demsetz, Saidenberg and Strahan [1996] argue that the franchise-value of banks also serves to inhibit extraordinary risk-taking - they find substantial evidence that the higher a bank's franchise value, the more prudent management tends to be. This suggests that large universal banks with high franchise values should serve shareholder interests (as well as the interests of the regulators) by means of appropriate risk management as opposed to banks with little to lose. 


\section{From Market Value of Equity to Potential Value of Equity}

The market capitalization of a universal bank is what it is, a product of a broad spectrum of quantifiable and not-so-quantifiable factors such as those discussed in the previous section. Looking ahead, managing for shareholder value means managing for return on investment, in effect maximizing the "potential value equity" (PVE) that the organization may be capable of achieving. In the merger market this would be reflected in the "control premium" that may appear between the bank's market capitalization and what someone else in a position to act thinks the bank is worth.

\section{The Chase is Dead. Long Live The Chase}

Take the case of Chase Manhattan. The bank had suffered for years from a reputation for underperformance and mediocrity, despite some improvement in its results, better strategic focus, improved efficiency levels and a cleaned-up balance sheet. In January 1995 , Chase's stock price was $\$ 34$, with a return on assets a bit under $1 \%$, a return on equity of about $15 \%$, a price-to-book ratio of about 1.2 and a price to earnings multiple of 7.0. Exhibit 10 shows Chase's stock price performance relative to the S\&P 500 and the S\&P Money Center Banks during 1991-94.

In April 1995, investment manager Michael Price, Chairman of Mutual Series Fund, Inc., announced that funds under his management had purchased 6.1 percent of Chase's stock, and that he believed the Chase board should take steps to realize the inherent values in its businesses in a manner designed to maximize shareholder value. At the bank's subsequent annual meeting, Price aggressively challenged the bank's 
management efforts: "Dramatic change is required. It is clear that the sale of the bank is superior to the company's current strategy...unlock the value, or let someone else do it for you."13 Chase's Chairman, Thomas Labreque, responded that he had no intention of selling or breaking-up the bank. By mid-June 1995 the Mutual Series Fund and other institutional investors, convinced that Chase stock was undervalued, were thought to have accumulated approximately $30 \%$ of the bank's outstanding shares and the stock price had climbed to about $\$ 47$ per share. Labreque announced that the bank was continuing its efforts to refocus the bank's businesses and to reduce costs.

During June and July of 1995, Chase and BankAmerica talked seriously about a merger in which the BankAmerica name would be retained. Then BankAmerica suddenly backed-out for reasons that were not totally clear to outsiders at the time. ${ }^{14}$ Chemical Bank followed quickly with a proposal for a "merger of equals." According to Chemical's chairman, Walter Shipley, "This combined company has the capacity to perform at benchmark standards. And when we say benchmark standards, we mean the best in the industry." ${ }^{15}$ Labreque agreed, and the negotiations were completed on 28 August 1995 . Chemical would offer to exchange 1.04 shares of its stock for every Chase share outstanding, an offer reflecting a $7 \%$ premium over the closing price of Chase shares on the day before the announcement.

The combined bank retaining the Chase name thus became the largest bank in

\footnotetext{
${ }^{13}$ The Wall Street Journal, May 19, 1995.

14/nstitutional Investor, November, 1995.

${ }^{15}$ ABC Evening News, August 28, 1995.
} 
the United States and 13th largest in the world in terms of assets. The new Chase also became the largest U.S. corporate lending bank, one of the largest credit card lenders, and the largest player in trust, custody, and mortgage servicing. Shipley became chief executive, and Labreque became president. Substantial cost-reduction efforts were quickly launched (including large-scale layoffs and branch closings) aimed at reducing the combined overhead of the two banks within three years by $16 \%$. In the month following the announcement of the merger, Chemical Bank's stock rose $12 \%$.

Labreque denied that shareholder pressure had anything to do with the merger. Michael Price asserted that he had not played a major role, but was happy to have been in the "right place at the right time." Nevertheless, adjusting for the exchange offer and the post-merger run-up in Chemical's share price, Chase shares more than doubled their value in a little over six months based on the market's assessment of the potential value imbedded in the merger. What was the source of the added value?

\section{Realizing the Potential Value of Equity}

Clearly, merger transactions in contestable markets for corporate control are-as in the case of Chase Manhattan-aimed at unlocking shareholder value. The intent is to optimize the building-blocks that make up potential value of equity as depicted in Exhibit 2-realizable economies of scale, economies of scope, X-efficiency, market power, and TBTF benefits, while minimizing value-losses from any diseconomies that may exist as well as avoiding to the extent possible conflict-of-interest problems and 
any conglomerate discount. Evidently the market agreed in this case, amply rewarding shareholders of both banks, especially those of the old Chase.

At least in the United States, bank acquisitions have occurred at price-to-book value ratios of about 2.0 , sometimes as high as 3.0 or even more. In eight of the eleven years in a recent study [Smith and Walter, 1996], the average price-to-book ratio for the U.S. banking industry acquisitions was below 2.0, averaging 1.5 and ranging from 1.1 in 1990 to 1.8 in 1985 . In two years, the price-to-book ratio exceeded 2.0 - in 1986 it was 2.8 and in 1993 in was 3.2. These values presumably reflect the opportunity for the acquired institutions to be managed differently and to realize the incremental value needed to reimburse the shareholders of the acquiring institutions for the willingness to pay the premium in the first place. If in fact the value-capture potential for universal banks exceeds that for U.S.-type separated commercial banks, this should be reflected in higher merger premiums in banking environments outside the United States.

Pressure for shareholder value optimization may not, of course, be triggered by an active and contestable market for corporate control, but it probably helps. Comparing cost, efficiency, and profitability measures across various national environments that are characterized by very different investor expectations and activism suggests that external pressure is conducive to realizing the potential value of shareholder equity in banking. In terms of Exhibit 2 and the empirical evidence available so far, the management lessons for universal banks appear to include the following: 
- Don't expect too much from economies of scale.

- Don't expect too much from supply-side economies of scope, and be prepared to deal with any diseconomies that may arise.

- Exploit demand-side economies of scope where cross-selling makes sense, most likely with retail, private and middle-market corporate clients.

- Optimize X-efficiencies through effective use of technology, reductions in the capital-intensity of financial services provided, reductions in the work force, and other available operating economies.

- Seek-out imperfect markets that demonstrate relatively low price-elasticity of demand, ranging from private banking services, equity transactions that exploit "fault lines" across capital markets, and leading-edge emerging-market transactions that have not as yet been commoditized, to dominant "fortress" market-share positions in particular national or regional markets, with particular client-segments, or in particular product-lines. The half-lives of market imperfections in banking differ enormously, and require careful calibration of delivery systems ranging from massive investments in infrastructure to small, light, entrepreneurial and opportunistic SWAT-teams. The key managerial challenge is to accommodate a broad array of these activities under the same roof.

- Specialize operations using professionals who are themselves specialists.

- Where possible, make the political case for backstops such as underpriced deposit insurance and TBTF support. Although this is a matter of public policy, shareholders clearly benefit from implicit subsidies that don't come with too many conditions attached.

- Pay careful attention to limiting conflicts of interest in organizational design, incentive systems, application and maintenance of Chinese walls, and managerial decisions that err on the side of caution where potential conflicts arise.

- Minimize the conglomerate discount by divesting peripheral nonfinancial shareholdings and non-core businesses, leaving diversification up to the shareholder. The gain in market value may well outweigh any losses from reduced scope economies and earnings-diversification. Pursuing this argument to its logical conclusion, of course, challenges the basic premise of universal banking as a structural form. 
- Get rid of share-voting restrictions and open-up shareholdings to market forces.

- Pay careful attention to the residual "franchise" value of the bank by avoiding professional conduct lapses that lead to an erosion of the bank's reputation, uncontrolled trading losses, or in extreme cases criminal charges against the institution. It's never a good idea to cut corners on compliance or building an affirmative "culture" which employees understand and value as much as the shareholders.

Exhibit 2 shows some of these as a "recapture" of shareholder-value losses in universal banks associated with diseconomies of scale and scope, conglomerate discount not offset by the benefits of a universal structure, and potential conflict-ofinterest and reputational losses. The balance of any further potential gains involves ramping-up key elements of the production function of the bank, capitalizing on market opportunities, and an intense focus on maximizing franchise-value and reputation.

If a strategic direction taken by the management of a universal bank does not exploit every source of potential value for shareholders, then what is the purpose? Avoiding an acquisition attempt from a better-managed suitor who will pay a premium price, as in the case of Chase Manhattan, does not seem as unacceptable today as it may have been in the past. In a world of more open and efficient markets for shares in financial institutions, shareholders increasingly tend to have the final say about the future of their enterprises. 


\section{References}

Akhavein, Jalal D., Allen N. Berger and David B. Humphrey, "The Effects of Megamergers on Efficiency and Prices: Evidence from a Bank Profit Function," paper presented at a Conference on Mergers of Financial Institutions, New York University Salomon Center, October 11, 1996.

Benston, George, "Universal Banking," Journal of Economic Perspectives, Volume 8, Number 3, Summer 1994.

Benston, George, G. Hanweck and D. Humphrey, "Scale Economies in Banking" Journal of Money, Credit and Banking, 14,1982.

Berger, Allen N., Diana Hancock and David B. Humphrey, "Bank Efficiency Derived from the Profit Function," Journal of Banking and Finance, April 1993.

Berger, Allen N., G. Hanweck, and D. Humphrey, "Competitive Viability in Banking" Journal of Monetary Economics, 20, 1987.

Berger, Allen N., William C. Hunter and Stephen J. Timme, "The Efficiency of Financial Institutions: A Review of Research Past, Present and Future," Journal of Banking and Finance, April 1993.

Berger, Philip G. and Eli Ofek, "Diversification's Effect on Firm Value," Journal of Financial Economics, 37, 1995.

Clark, Jeffrey A., "Economies of Scale and Scope at Depository Financial Institutions: a Review of the Literature" Federal Reserve Board of Kansas City Review, October 1988.

Demsetz, Rebecca S., Marc R. Saidenberg and Philip E. Strahan, "Banks with Something to Lose: The Disciplinary Role of Franchise Value," Federal Reserve Bank of New York Policy Review, October 1996.

Economides, Nicholas, "Network Economics with Application to Finance," Financial Markets, Institutions and Instruments, Vol. 2, No. 5, 1993.

Fields, Joseph A. and Neil B. Murphy, "An Analysis of Efficiency in the Delivery of Financial Services: The Case of Life Insurance Agencies," Journal of Financial Services Research, 2, 1989.

Gilligan, Thomas and Michael Smirlock, "An Empirical Study of Joint Production and Scale Economies in Commercial Banking," Journal of Banking and Finance, 8, 1984. 
Gilligan, Thomas, Michael Smirlock and William Marshall, "Scale and Scope Economies in the Multi-Product Banking Firm," Journal of Monetary Economics, 13, 1984.

Gnehm, A. and C. Thalmann, "Conflicts of Interest in Financial Operations: Problems of Regulation in the National and International Context," Working Paper, Swiss Bank Corporation, Basel, 1989.

Goldstein, Steven, James McNulty, and James Verbrugge, "Scale Economies in the Savings and Loan Industry Before Diversification," Journal of Economics and Business, 1987.

Hawawini, Gabriel and Itzhak Swary, Mergers and Acquisitions in the U.S. Banking Industry (Amsterdam: North Holland, 1990).

John, Jose and Eli Ofek, "Asset Sales and Increase in Ficus," Journal of Financial Economics, 37, 1995.

Kellner, S. and G Frank Mathewson, "Entry, Size Distribution, Scale and Scope Economies in the Life Insurance Industry," Journal of Business, 1983.

Kim, H. Youn, "Economies of Scale and Scope in Multiproduct Financial Institutions," Journal of Money, Credit and Banking, 18, 1986.

Kolari, James and Asghar Zardhooki, Bank Cost Structure and Performance (Lexington, Mass.: Heath Lexington, 1987).

Lawrence, Colin, "Banking Costs, Generalized Functional Forms, and Estimation of Economies of Scale and Scope," Journal of Money, Credit and Banking, Vol. 21, No. $3,1989$.

Mester, Loretta, "A Multiproduct Cost Study of Savings and Loans," Journal of Finance, 42, 1987.

Mester, Loretta, "Traditional and Nontraditional Banking: an Information Theoretic Approach," Federal Reserve Board Working Paper, No. 90-3, February 1990.

Murray, John D. and Robert S. White, "Economies of Scale and Economies of Scope in Multiproduct Financial Institutions," Journal of Finance, June 1983.

Noulas, Athanasios G., Subhash C. Ray and Stephen M. Miller, "Returns to Scale and Input Substitution for Large U.S. Banks," Journal of Money, Credit and Banking, Vol. 22, 1990. 
Saunders, Anthony, Financial Institutions Management, Second Edition (Burr Ridge, III.: Irwin, 1996).

Saunders, Anthony and Ingo Walter, Universal Banking in the United States (New York: Oxford University Press, 1994).

Saunders, Anthony and Ingo Walter (eds.), Universal Banking: Financial System Design Reconsidered (Burr Ridge, III.: Irwin, 1996).

Shaffer, Sherrill, "A Restricted Cost Study of 100 Large Banks," Federal Reserve Bank of New York Working Paper, 1988.

Thomas F. Siems, "Bank Mergers and Shareholder Value: Evidence from 1995's Megamerger Deans," Federal Reserve Bank of Dallas Financial Industry Studies, August 1996.

Smith, Roy C. and Ingo Walter, "Global Patterns of Mergers and Acquisitions in the Financial Services Industry," paper presented at a Conference on Mergers of Financial Institutions, New York University Salomon Center, October 11, 1996.

Smith, Roy C. and Ingo Walter, Global Banking (New York: Oxford University Press, 1997A).

Smith, Roy C. and Ingo Walter, Street Smarts: Leadership and Shareholder Value in the Securities Industry (Boston: Harvard Business School Press, 1997B).

Steinherr, Alfred, "Performance of Universal Banks: Review and Appraisal," in Anthony Saunders and Ingo Walter (eds.), Universal Banking: Financial System Design Reconsidered (Burr Ridge, III.: Irwin, 1996).

Tschoegl, Adrian E. , "Size, Growth and Transnationality among the World's Largest Banks," Journal of Business, Vol. 56, No. 2, 1983.

Walter, Ingo (ed.), Deregulating Wall Street (New York: John Wiley \& Sons, 1985).

Walter, Ingo, Global Competition in Financial Services (Cambridge: Ballinger-Harper \& Row, 1988).

Walter, Ingo, The Battle of the Systems: Control of Enterprises in the Global Economy (Kiel: Kieler Studien Nr. 122, Institut für Weltwirtschaft, 1993).

Yoshioka, Kanji and Takanobu Nakajima, "Economies of Scale in Japan's Banking Industry," Bank of Japan Monetary and Economic Studies, September 1987. 


\section{Exhibit 1 \\ Universal Bank Organization Structures}

Type-A: FULL INTEGRATION

UNIVERSAL BANK

\begin{tabular}{|c|l|l|l|}
\hline $\begin{array}{c}\text { Bank } \\
\text { Activities }\end{array}$ & $\begin{array}{l}\text { Securities } \\
\text { Activities }\end{array}$ & $\begin{array}{l}\text { Insurance } \\
\text { Activities }\end{array}$ & Other \\
\hline
\end{tabular}

Type-B: PARTIAL INTEGRATION

UNIVERSAL BANK

Banking Activities and Securities Activities

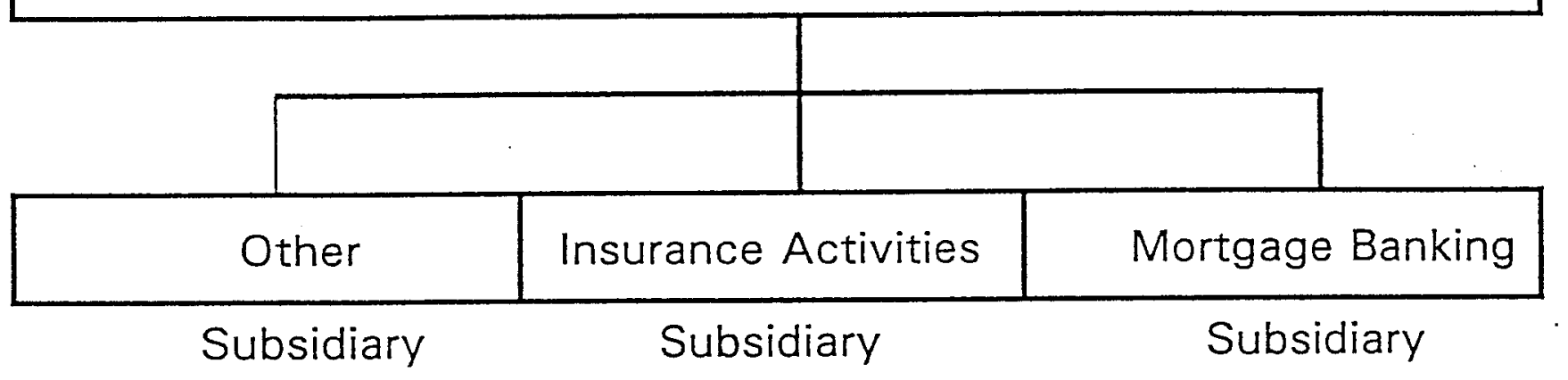

Type-C: BANK PARENT STRUCTURE

UNIVERSAL BANK

Banking Activities

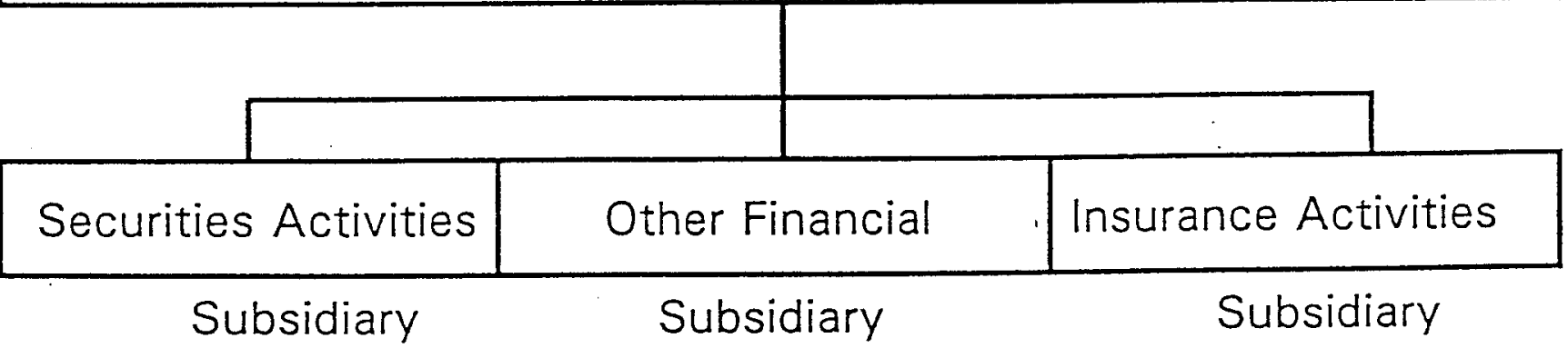

Type-D: HOLDING COMPANY STRUCTURE

HOLDING COMPANY

Banking Activities

\begin{tabular}{l|l|} 
Securities Activities & Insurance Activities \\
\hline
\end{tabular}

Subsidiary

Subsidiary

Subsidiary 


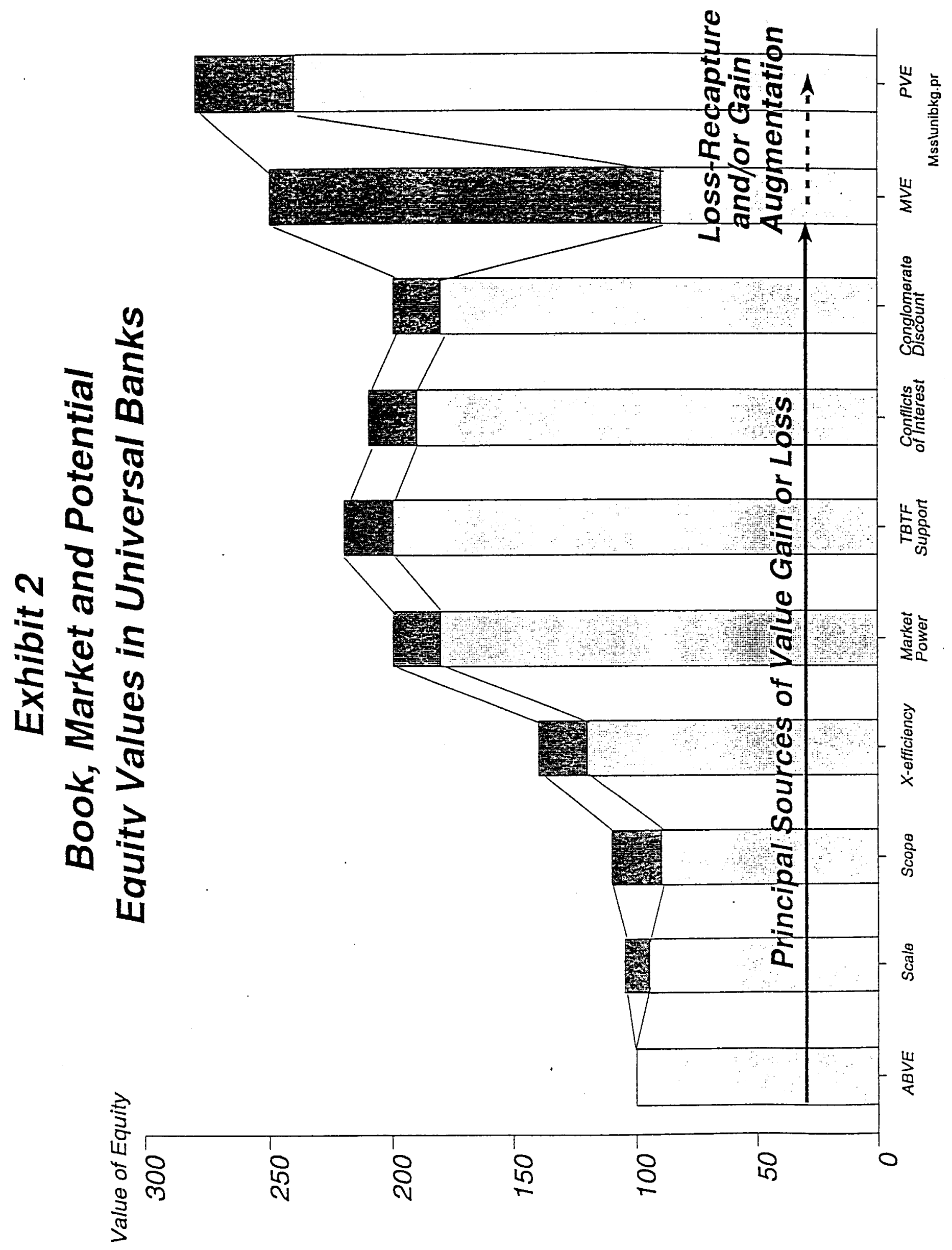




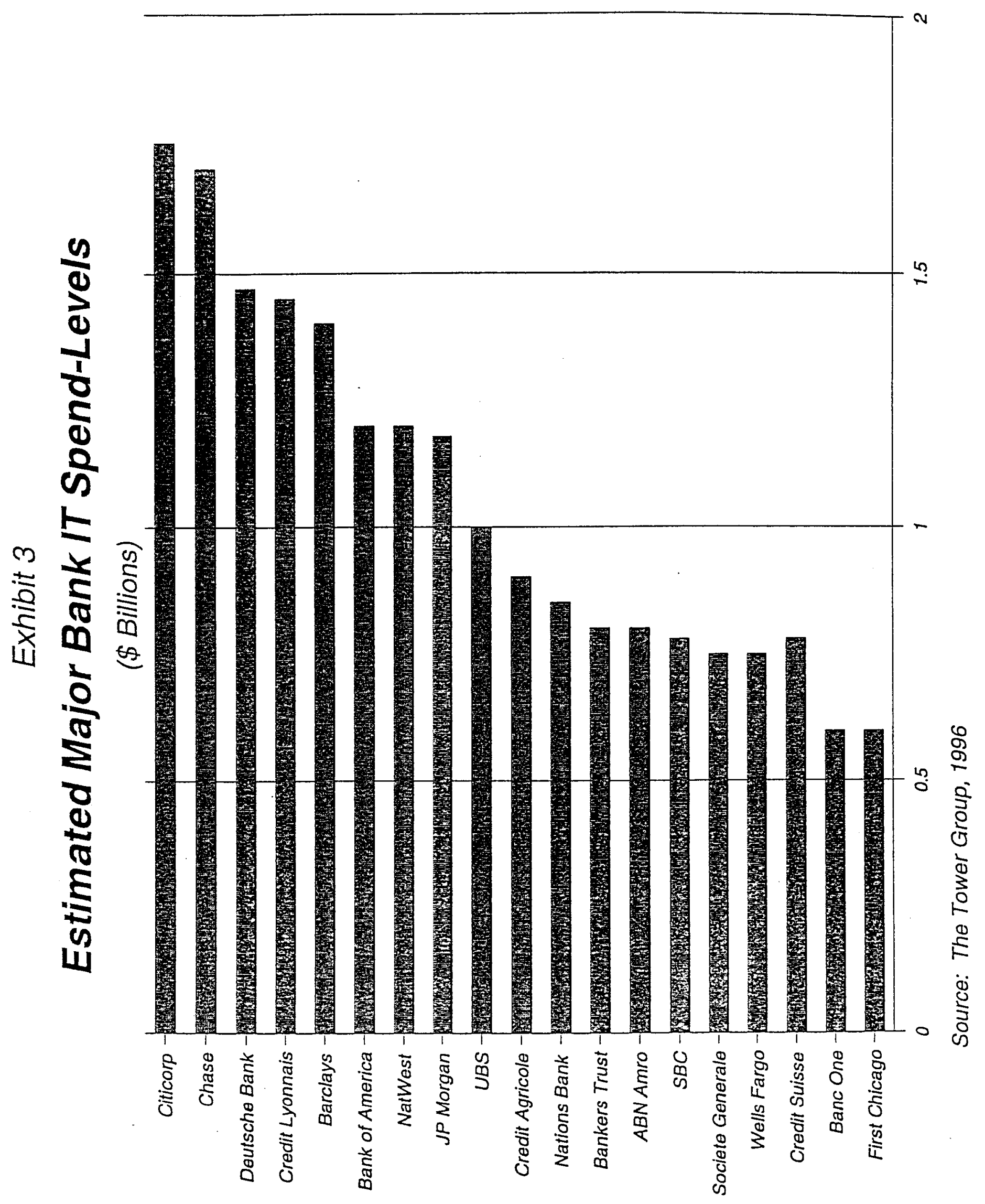




\section{Exhibit 4}

Economies of Scale and Scope in Financial

Services Firms - The Evidence

\begin{tabular}{|c|c|c|}
\hline & $\begin{array}{c}\text { Economies of Scale } \\
\text { beyond Small Levels } \\
\text { of Output (size) }\end{array}$ & $\begin{array}{l}\text { Economies of } \\
\text { Scope among } \\
\text { Outputs }\end{array}$ \\
\hline \multicolumn{3}{|l|}{ Domestic Banks } \\
\hline Benston et al., 1983 & No & No \\
\hline Berger et al., 1987 & No & No \\
\hline Gilligan and Smirlock, 1984 & No & Yes \\
\hline Gilligan, Smirlock, and Marshall, 1984 & No & Yes \\
\hline Kolari and Zardkoohi, 1987 & No & No \\
\hline Lawrence, 1989 & No & Yes \\
\hline Lawrence and Shay, 1986 & No & No \\
\hline Mester, 1990 & Yes & No \\
\hline Noulas et al, 1990 & Yes & $?$ \\
\hline Shaffer, 1988 & Yes & ? \\
\hline Hunter et. al., 1990 & Yes & No \\
\hline McAllister and McManus, 1993 & No & $?$ \\
\hline Pulley and Humphrey, 1993 & $?$ & Yes \\
\hline \multicolumn{3}{|l|}{ Foreign Banks } \\
\hline Yoshika and Nakajima, 1987 (Japan) & Yes & $?$ \\
\hline Kim, 1987 (Israel) & Yes & Yes \\
\hline Saunders and Walter, 1991 (Worldwide) & Yes & No \\
\hline Rothenberg, 1994 (European Community) & No & $?$ \\
\hline \multicolumn{3}{|l|}{ Thrifts } \\
\hline Mester, 1987 & No & No \\
\hline LeCompte and Smith, 1990 & No & No \\
\hline \multicolumn{3}{|l|}{ Life Insurance } \\
\hline Fields and Murphy, 1989 & Yes & No \\
\hline Fields, 1988 & No & $?$ \\
\hline Grace and Timme, 1992 & Yes & $?$ \\
\hline \multicolumn{3}{|l|}{ Securities Firms } \\
\hline
\end{tabular}




\section{Exhibit 5(a)}

\section{Global Wholesale Banking and Investment Banking 1995 \\ Full Credit to Book Running Manager Only}

(\$ billions)

\begin{tabular}{|c|c|c|c|c|c|c|}
\hline Firm & $\begin{array}{l}\text { Global Debt } \\
\text { \& Equity } \\
\text { Securities } \\
\text { Underwriting } \\
\text { \& Placement } \\
\text { (a) }\end{array}$ & $\begin{array}{l}\text { Global } \\
\text { M\&A } \\
\text { Advisory } \\
\text { (b) }\end{array}$ & $\begin{array}{l}\text { Int'l } \\
\text { Loans } \\
\text { Arranged } \\
\text { (c) }\end{array}$ & $\begin{array}{l}\text { Medium } \\
\text { Term } \\
\text { Notes } \\
\text { Lead } \\
\text { Managed } \\
\quad \text { (d) }\end{array}$ & Total & $\begin{array}{l}\% \text { of } \\
\text { Industry } \\
\text { Total }\end{array}$ \\
\hline Merrill Lynch & 173.43 & 34.76 & 2.00 & 208.80 & 418.99 & $10.8 \%$ \\
\hline CS/First Boston & 109.58 & 66.22 & 45.90 & 69.00 & 290.70 & $7.5 \%$ \\
\hline Chemical/Chase & 11.30 & - & 272.40 & - & 283.70 & $7.3 \%$ \\
\hline JP Morgan & 76.32 & 53.72 & 128.60 & - & 258.64 & $6.7 \%$ \\
\hline Morgan Stanley & 104.52 & 113.77 & - & 18.00 & 236.29 & $6.1 \%$ \\
\hline Goldman Sachs & 96.44 & 83.64 & 2.00 & 39.06 & 221.14 & $5.7 \%$ \\
\hline Lehman Brothers & 91.15 & 46.17 & - & 55.00 & 192.32 & $5.0 \%$ \\
\hline Salomon Brothers & 82.28 & 39.34 & - & 21.40 & 143.91 & $3.7 \%$ \\
\hline Citicorp & 10.70 & - & 116.50 & 10.30 & 137.50 & $3.6 \%$ \\
\hline Bear Stearns & 38.31 & 47.81 & - & 31.50 & 117.62 & $3.0 \%$ \\
\hline SBC Warburg & 36.75 & 31.50 & 11.30 & - & 79.55 & $2.1 \%$ \\
\hline Deutsche MG & 23.87 & 21.35 & 20.40 & 12.50 & 78.12 & $2.0 \%$ \\
\hline UBS & 30.06 & 15.81 & 31.10 & - & 76.97 & $2.0 \%$ \\
\hline Lazard Houses & - & 75.45 & - & - & 75.45 & $2.0 \%$ \\
\hline NationsBank & 18.40 & - & 38.90 & 13.00 & 70.30 & $1.8 \%$ \\
\hline Smith Barney & 29.33 & 25.75 & - & 5.96 & 61.04 & $1.6 \%$ \\
\hline ABN/Amro & 20.94 & - & 23.10 & 7.50 & 51.54 & $1.3 \%$ \\
\hline Bank of America & 7.00 & - & 42.20 & - & 49.20 & $1.3 \%$ \\
\hline Nomura & 48.32 & - & - & - & 48.32 & $1.2 \%$ \\
\hline DLJ & 32.26 & 14.83 & - & - & 47.09 & $1.2 \%$ \\
\hline Total Industry & 1535.1 & 575.80 & 1098.40 & 656.70 & 3866.00 & $100.0 \%$ \\
\hline $\begin{array}{l}\text { Top } 10 \% \text { as } \% \\
\text { of Total }\end{array}$ & $51.72 \%$ & $84.31 \%$ & $51.66 \%$ & $68.99 \%$ & $59.49 \%$ & $59.49 \%$ \\
\hline $\begin{array}{l}\text { Top } 20 \text { as } \% \\
\text { of Total }\end{array}$ & $67.81 \%$ & $116.38 \%$ & $66.86 \%$ & $74.92 \%$ & $75.98 \%$ & $75.98 \%$ \\
\hline
\end{tabular}

(a) Global rankings, top 25, completed deals only, including all U.S. private placements. Securities Data Corp.

(b) By market value of completed global transactions, full credit to both advisors, top 25 advisors; Securities Data Corp.

(c) Full credit to book manager, top 25 managers as reported, IFR International Financing Review, Jan. 20, 1996.

(d) Global MTNs, top 25 managers, Securities Data Corp. 
Exhibit 5(b)

Global Wholesale Banking: Market Concentration

\begin{tabular}{|c|c|c|c|c|c|c|}
\hline & 1990 & 1991 & 1992 & 1993 & 1994 & 1995 \\
\hline $\begin{array}{l}\text { Top Ten } \\
\text { \% of Market } \\
\text { Herfindahl Index } \\
\text { No. of firms } \\
\text { from: } \\
\text { USA } \\
\text { Europe } \\
\text { Japan }\end{array}$ & $\begin{array}{r}40.6 \\
171.6 \\
\\
\\
5 \\
5 \\
0\end{array}$ & $\begin{array}{r}46.1 \\
230.6 \\
\\
\\
\\
7 \\
3 \\
0\end{array}$ & $\begin{array}{r}56.0 \\
327.8\end{array}$ & $\begin{array}{r}64.2 \\
459.4\end{array}$ & $\begin{array}{r}62.1 \\
434.1\end{array}$ & $\begin{array}{r}59.5 \\
403.0 \\
\\
\\
9 \\
1 \\
0\end{array}$ \\
\hline $\begin{array}{l}\text { Top Twenty } \\
\text { \% of Market } \\
\text { Herfindahl Index } \\
\text { No. of firms } \\
\text { from: } \\
\text { USA } \\
\text { Europe } \\
\text { Japan }\end{array}$ & & & $\begin{array}{r}80.5 \\
392.7\end{array}$ & $\begin{array}{r}75.6 \\
478.4\end{array}$ & $\begin{array}{r}78.1 \\
481.4\end{array}$ & $\begin{array}{r}14 \\
5 \\
1 \\
\end{array}$ \\
\hline
\end{tabular}




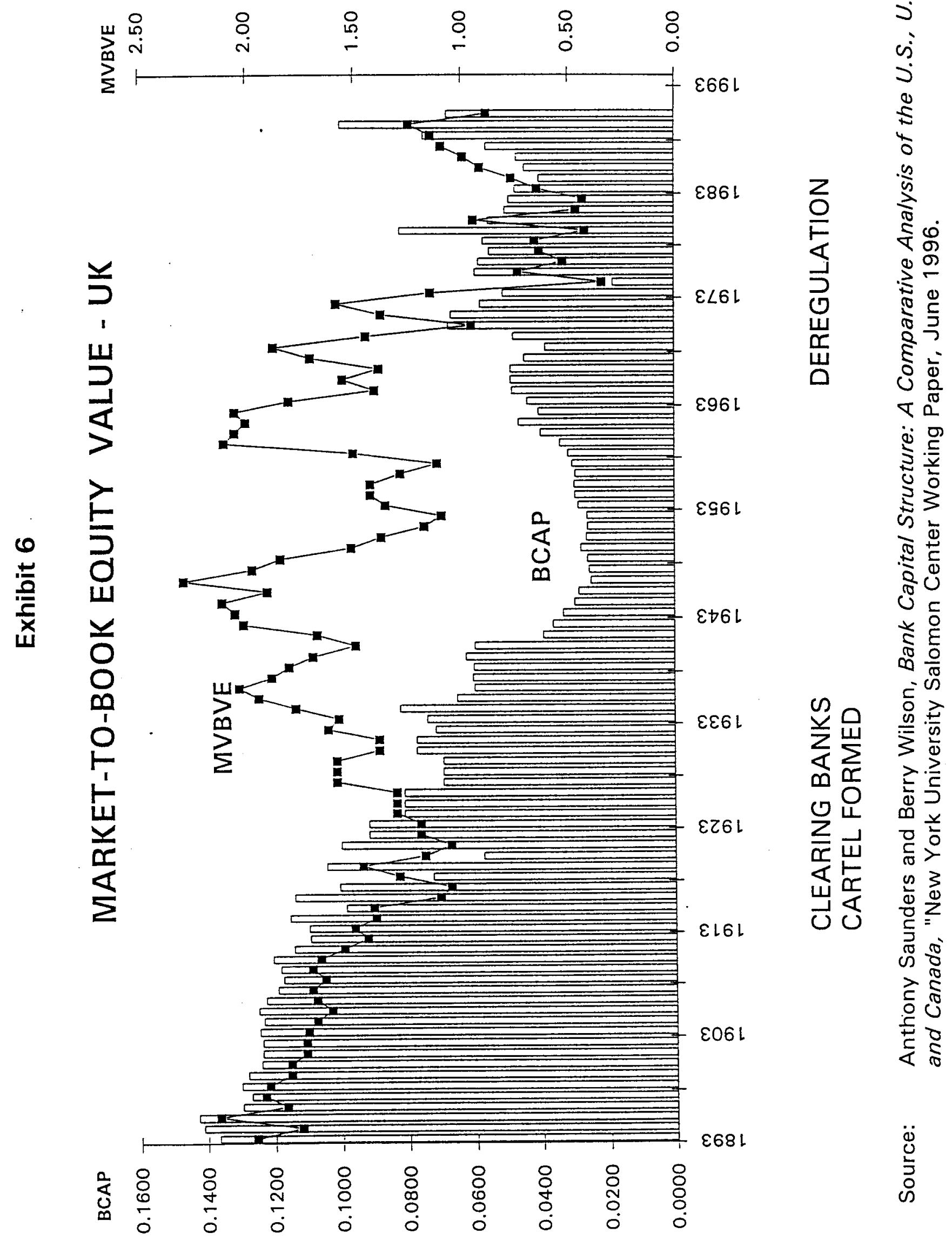




\section{Exhibit 7}

Price to Book Ratios of U.S. Money-Center and Major Regional Banks

\begin{tabular}{|c|c|c|c|c|c|}
\hline & $30 / 96$ & $20 / 96$ & $10 / 96$ & $40 / 95$ & 3095 \\
\hline Money Center Banks & & & & & \\
\hline Average & 191 & 166 & 165 & 152 & 150 \\
\hline BankAmerica & 172 & 159 & 151 & 134 & 135 \\
\hline Bank of Boston & 222 & 170 & 163 & 153 & 173 \\
\hline Bankers Trust & 157 & 138 & 135 & 124 & 123 \\
\hline Chase Manhattan & 196 & 169 & 170 & 155 & 137 \\
\hline Citicorp & 246 & 214 & 216 & 186 & 174 \\
\hline First Chicago & 183 & 149 & 161 & 150 & 149 \\
\hline JP Morgan & 164 & 162 & 160 & 159 & 156 \\
\hline Major Regional Banks & & & & & \\
\hline Average & 221 & 188 & 217 & 205 & 199 \\
\hline Banc One & 219 & 178 & 185 & 179 & 179 \\
\hline Corestate Financial & 258 & 219 & 220 & 226 & 229 \\
\hline First Union & 218 & 193 & 187 & 179 & 153 \\
\hline Fleet Financial & 200 & 169 & 187 & 174 & 144 \\
\hline Nations Bank & 199 & 181 & 174 & 147 & 158 \\
\hline Norwest Corp. & 276 & 228 & 250 & 229 & 225 \\
\hline Wells Fargo & 177 & 150 & 313 & 299 & 308 \\
\hline
\end{tabular}




\section{Exhibit 8 \\ Universal Banking Conflict Matrix}
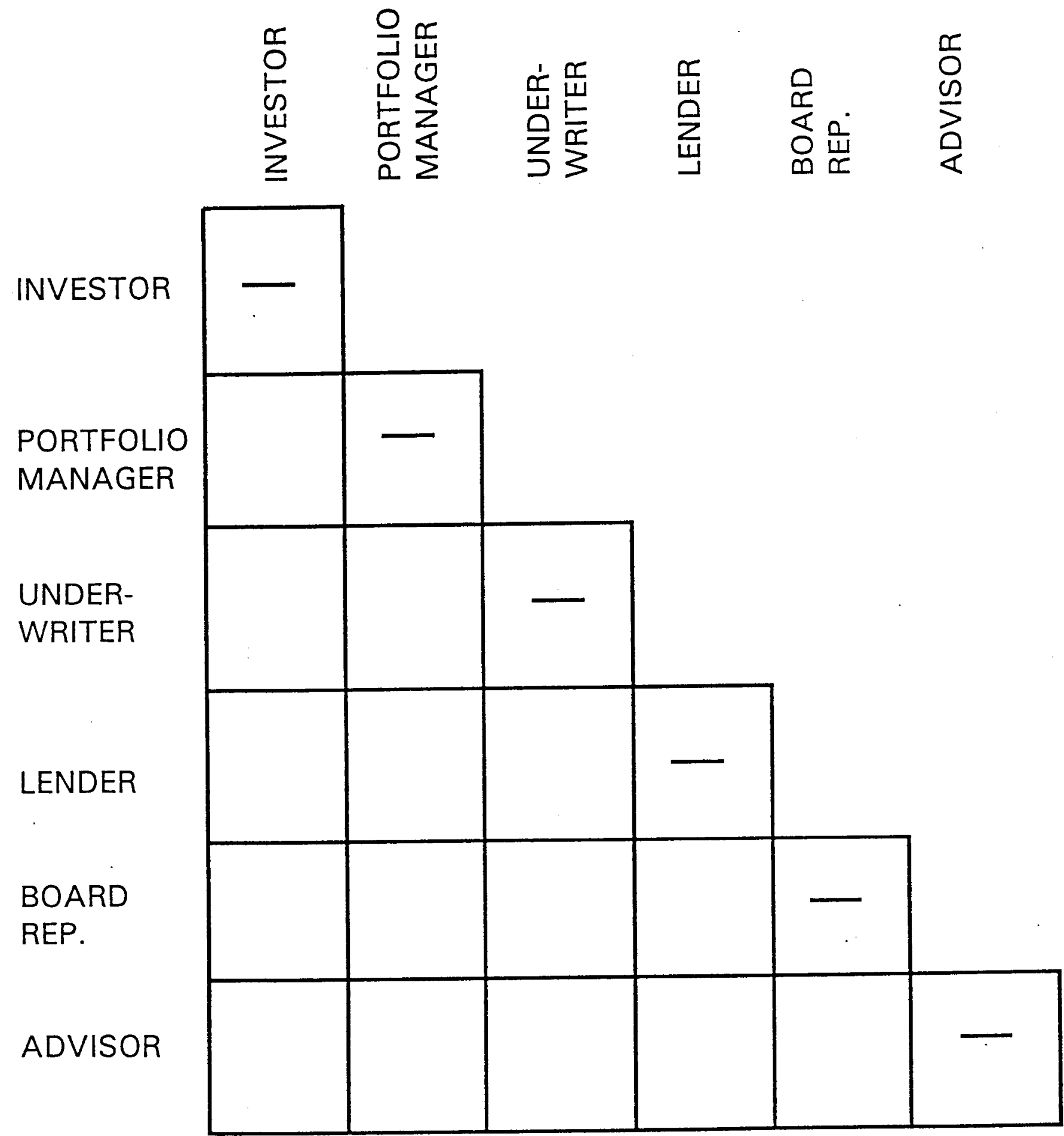


\section{Exhibit 9 \\ Alternative Bank-Industry Linkages}

1. The Equity-Market System

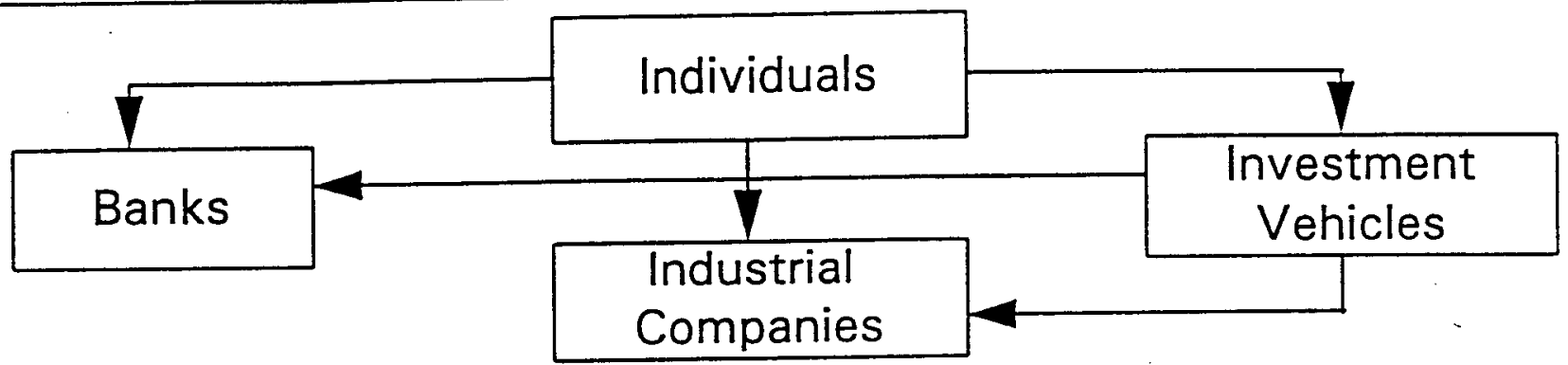

2. The Bank-Based System

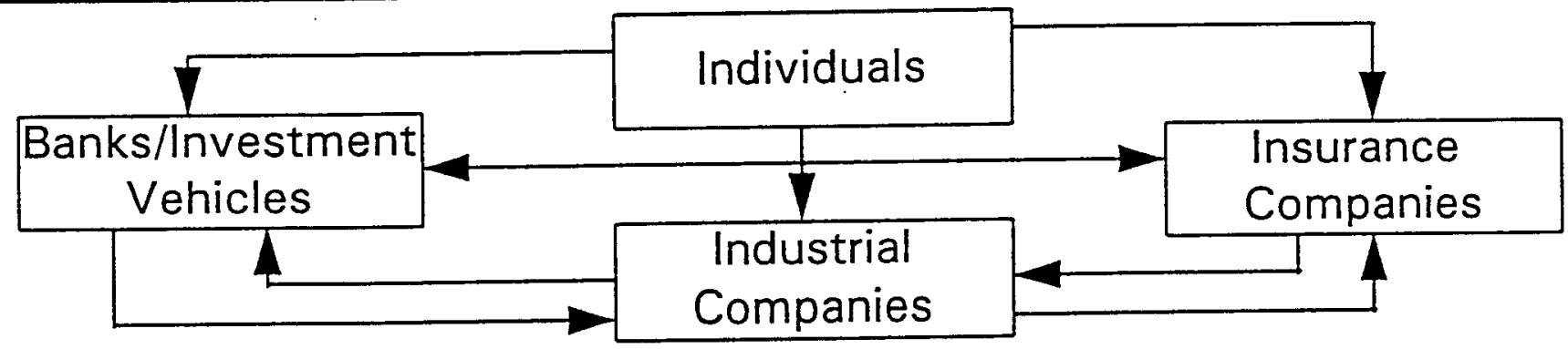

3. The Bank-Industrial Cross-

holding System

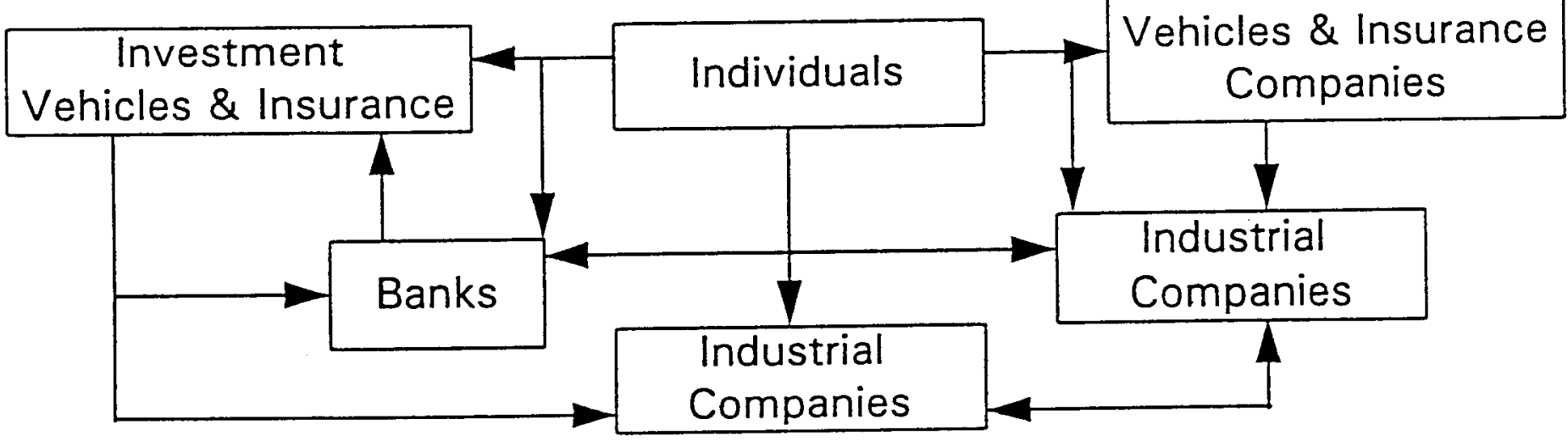

4. The State-centered System

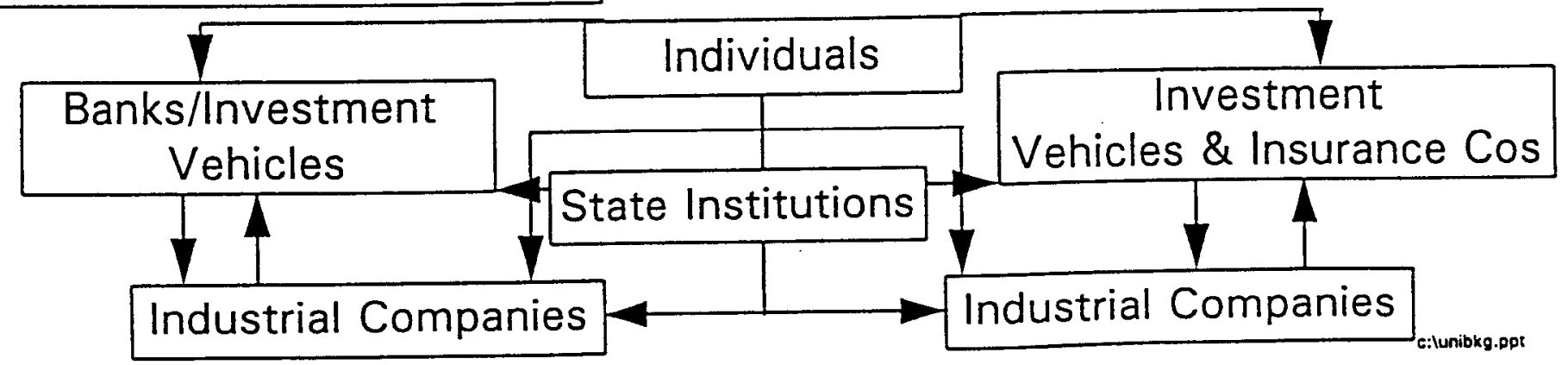




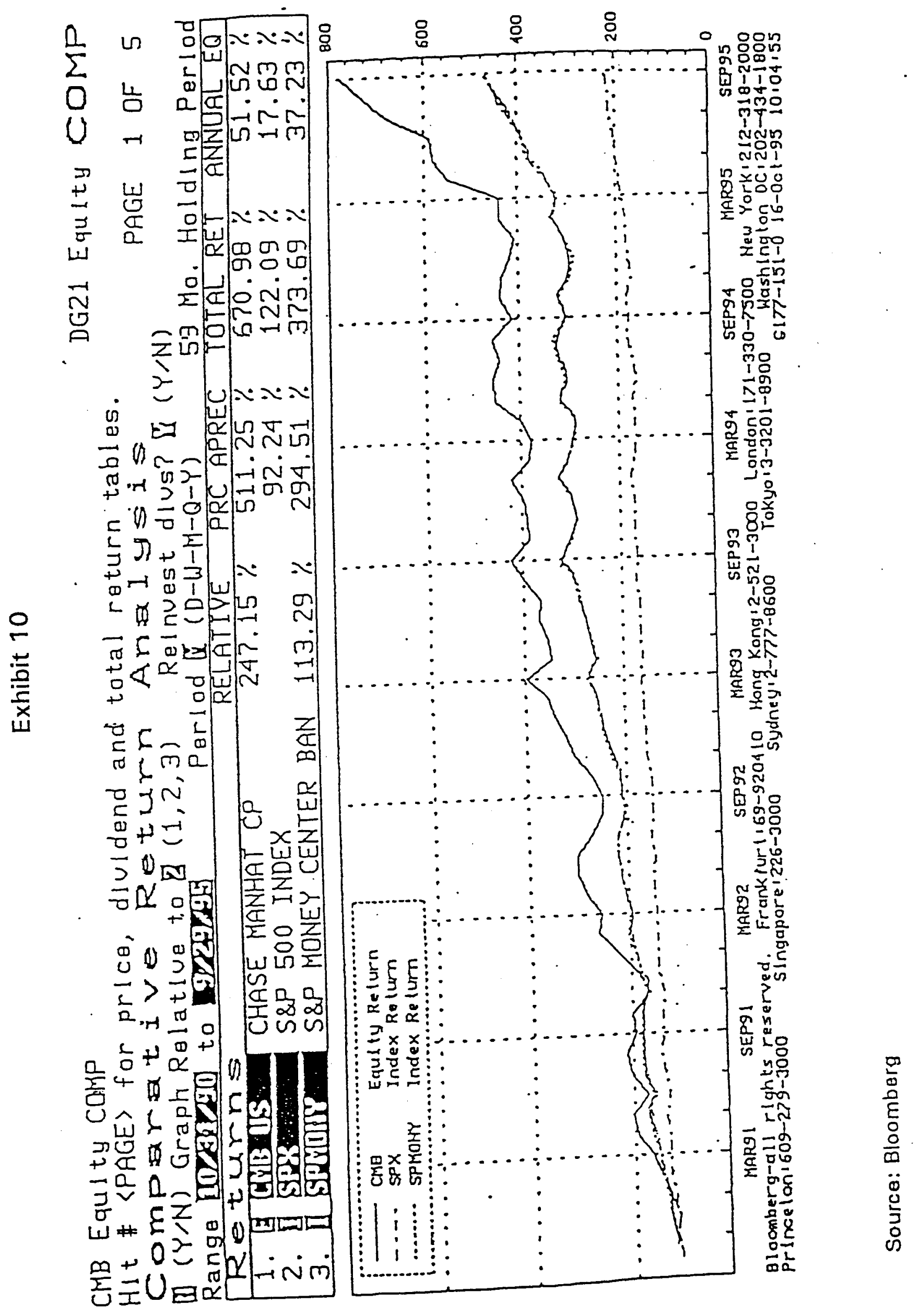

